\title{
The Development of Stereotypical Representations of Gender in Selected Disney Films \\ A Feminist Reading
}

\section{* Ms. Asmaa Ali Ibrahim Ali}

\section{Abstract}

This paper starts with an introduction illustrating the rationale behind the choice of the topic and the research objectives. Then, literature review spans the books, dissertations and articles both on gender stereotypes and gender role in recent Disney films. Then, through the feminist film theoretical framework, the paper studies Moana as a positive heroine, who is not a princess, but the daughter of the chief of her tribe and Maui, the demi-god, and how the relationship between both of them influences each other in their representation of gender values.

Also, this paper aims at analyzing the motifs that portray Moana, as a progressive female character as opposed to Disney princesses, and Maui's development as a positive role model for the male audience. The study also sheds light on some gender stereotypical traits that still exist in Moana and Maui. Finally, the study ends with a conclusion of how gender stereotypes are portrayed in recent Disney animated films and how those stereotypes have changed over time.

Key Words: Stereotypes, Gender, Gender role, Disney films

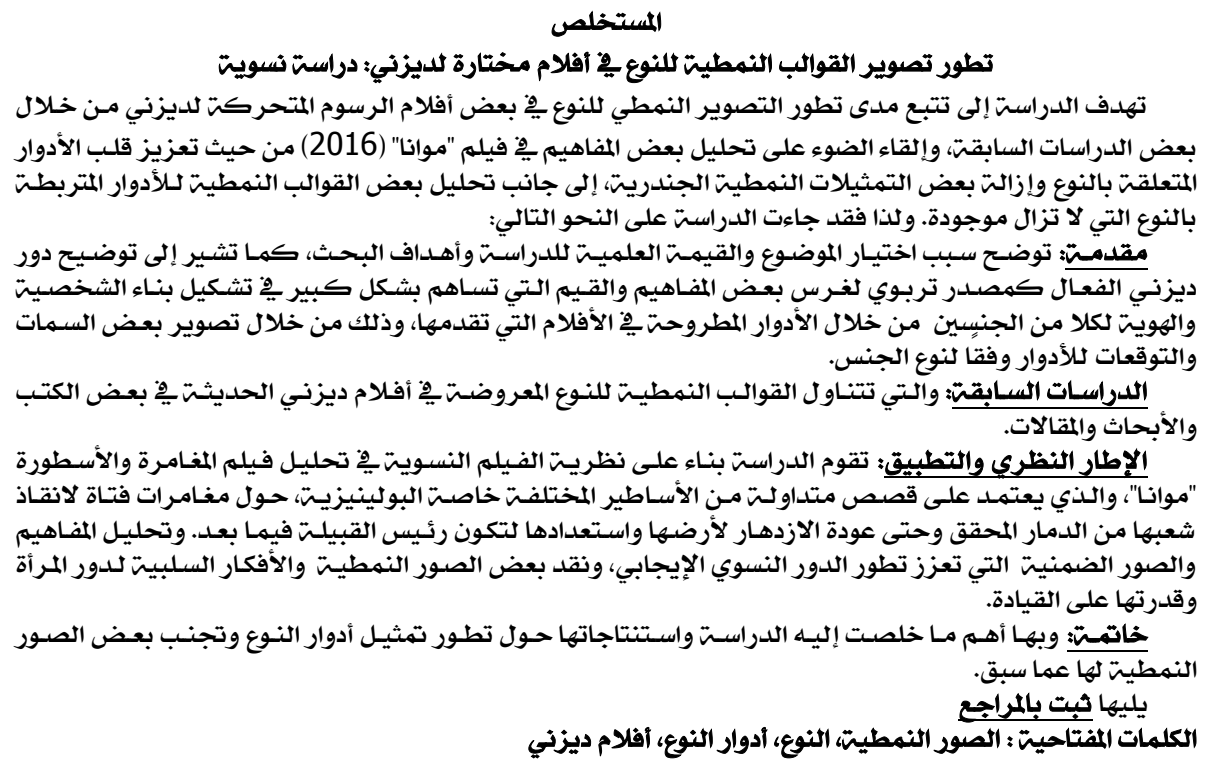

MA Researcher at the Faculty of Arts - Department of English Language and Literature Damanhour University

Teaching Assistant at the Faculty of Education for Early Childhood - Alexandria University Email:dr-asmaa.ali@alexu.edu.eg 


\section{Introduction}

Children use many internal and external factors including: picture books, fairy tales, animation films and visual art to frame their conceptions of male and female, appropriate gendered behaviors and their potential success as adults. Indeed, it is evident how the creation of stereotypes dictates their interactions with the opposite sex and their expectations in many aspects of their life, exemplifying the 'Perfect Girl', a concept that represents the submissive female. Despite their divine beauty, the princesses of most of the classic Disney films only seem to be capable of suffering in silence, and that is why, they are finally given the ultimate reward: salvation through the handsome 'Prince Charming'.

Many fairy tales have become even more popular after having been adapted into the animated films that act as a form of didactic literature that has been used in classrooms since the nineteenth century. Gender represents and reproduces certain attributes, expectations and roles which are associated with the dichotomies of male and female. Due to the importance of media as a resource through which people develop their identities, they come to understand the role that gender plays in the actual world. Disney films are often criticized for their negative, stereotypical portrayal of female characters, who often have certain traits in common. The female protagonist, who is shown as a 'Disney Princess', yet, the traits of these princesses, featured almost through each film are submissiveness and servitude.

Though some traditional stereotypes and concepts are still presented in many of Disney's recent animated and non-animated films, they have started to demonstrate examples of leadership, gender equality and even reversal of gender roles. They also highlight the societal shift to accepting and appreciating strong female leadership by utilizing characters that are successful and able to overcome their obstacles, almost without major male assistance.

This study focuses on the development of stereotypical representations of gender and its influence on children, in general, and on young girls, in particular. This paper will examine selected-recent Disney films to trace the development of various stereotypical representations of 
Disney female protagonists and their roles. Most of the research on Disney films has been centered on 'Disney Princesses'.

This paper studies Moana (2016) as it is considered by many critics to offer an alternative princess in contrast to the traditional ones. It is claimed that this film breaks with patriarchal and sexist values usually attributed to other princess films. Therefore, the character of Moana has been studied as a feminine role model. Nevertheless, little importance has been paid to the character of Maui, the demi-god that causes the main crisis in the plot and that accompanies Moana in her journey. Throughout their journey, it is noticed that Moana is not only portrayed as a positive heroine who breaks tribal conventions and patriarchal norms, but the gender roles is also reversed when she is depicted as the persistent girl, who, in contrast to Maui, wants to save her tribe utilizing her mind rather than her feelings until she succeeds at the end.

\section{Literature Review}

This paper is dedicated to examining the books and articles analyzing gender stereotypes and gender roles in cinema, in general, and in Disney, in particular. Most of the earlier critical studies conducted on Disney films focus on analytical analysis on gender, race and stereotypes.

\subsection{The Impact of Media on Children's Attitudes towards Gender Roles}

Since gender is not only biologically specified, it also includes a combination of coordinated mix of beliefs, behaviors, attitudes and characteristics. This complex coordination forms the core of gender identity, which determines the way of expressing gender and gender roles either through external personal appearance like clothing, or internal attitude of behavior and conduct in certain societies. This is clear through many studies based on children's attitudes and beliefs after being exposed to some external motives. For example, in the research Children's Accounts of Sex-role Stereotypes in Television, Kevin Durkin has studied the knowledge young children have about sex-stereotypes and the influence stereotypical gender depictions on television have on these children and their beliefs. He found that children between the age of four and nine already have knowledge on gender role division. Durkin states that "the more sex-stereotyped television children are exposed to, the 
more sex stereotyped their own attitudes and beliefs become" (Durkin, 1984:356). Thus, the way gender roles are depicted on television influences the minds of children.

In addition, the concept of the urge for marriage as a dream to be achieved, which is highlighted in Disney animated films, is argued by Nancy F. Cott in her study A History of Marriage and the Nation. She claims that from "the founding of the United States to the present day, assumptions about the importance of marriage and its appropriate form have been deeply implanted in public policy" (Cott, 2009:2). The Disney animation features imply that it is the most important goal for a woman to find a husband, or, more often, she just waits till he finds her.

What is more, Joseph Tobin conducted his study on non-animated films at Koa Elementary School in Pearl City, Hawaii, entitled Good Guys Don't Wear Hat: Children's Talk about the Media. He had three main groups, eight all girl-focus groups, eight all boy-focus groups, and sixteenmixed groups and showed them clips from Swiss Family Robinson and The Black Stallion. From the study, he looked to see what children knew about media representations of violence, race, and gender, and to see how they interacted with one another. The girls displayed empathy for victims in the films, while the boys displayed their hyper-masculine tastes and demeanor by often attacking the girls' interests (Tobin, 2000:34). Tobin suggests it may be because it is the only way they know how to perform their masculinity (Tobin, 2000:33). Yet, boys who stepped out of line (for example, one boy admitted to liking Barbie) were reprimanded and humiliated by the other boys in his group, who teased him for this "feminine" interest (Tobin, 2000:43).

The former example actively shows the concept of being marginalized for being The Other in Emma Renold's book Girls, Boys and Junior Sexualities: Exploring Children's Gender and Sexual Relations in the Primary School. The reason for this avoidance of media that presents a content contradictory to typical gender inclinations and stated gender roles, from the rest of the students, may be for the fear of being 'othered' and the repercussions that follow like what happened with the boy, who liked girls' things. The most surprising finding was that the children more strongly gender-stereotyped the male film than the female film(Renold, 2005:84). Therefore, this finding may be the exception to former conclusions 
that girls are more likely to accept masculine things than boys are to accept feminine things.

Accordingly, in an attempt to assert the idea that gender frames the way of behavior in relation to the social expectations and social norms, Aaron Devor employs an educational approach, in his research Becoming Members of Society: Learning the Social Meanings of Gender, through which he describes gender stereotypes through cultural references. He differentiates between femininity and masculinity, describing the lifelong construction of gender identity (Devor, 1992:23). He finds that children watching Disney films are indeed aware of the gender 'performance'; accordingly, they anticipate how characters should behave and judge their actions against set social 'norms'. He actually generalizes that most people in North America often perceive femininity and masculinity in binary opposition (Devor, 1992:28), as being the 'One' and the 'Other'.

In her study Escape from Wonderland: Disney and the Female Imagination, Deborah Ross argues that these films give children ideas about the value of their own imaginations (Ross, 2004:54). Films such as Alice in Wonderland suggest that adventure is something that good girls should be wise enough to avoid (Ross, 2004:56), supporting the idea of 'The Perfect Girl'. Alice wants to escape boredom, satisfy her curiosity, and exert power, but in the end, she needs to be rescued (Ross, 2004:57). Ross explains that the trickiest part of this example is that Disney suggests that children should not follow in Alice's footsteps and use their imagination. Rather, they should feel guilty and ashamed for this type of behavior (Ross, 2004:58). "Disney movies implant seeds of guilt and fear to spring up along with children's developing imaginations", which is a serious problem (Ross, 2004:63).

\section{2. 'The Perfect Girl' in Disney Films}

In their book Construction of the Female Self: Feminist Readings of the Disney Heroine, Jill B. Henke, Diane Z. Umble, and Nancy J. Smith examine how the female protagonists are constructed in five Disney Princess films: Cinderella, Sleeping Beauty, The Little Mermaid, Beauty and the Beast, and Pocahontas. In their discussion of the term 'the Perfect Girl', it has been portrayed through the depiction of the early heroines such as 
Cinderella and Aurora, who are the helpless, passive victims in need of protection (Henke et al., 1996:234). Progress has been made in the portrayal of later princesses, such as Belle and Pocahontas who exercise some power over their future (Henke et al., 1996:239). In recent films, they conclude that princesses have been increasingly able to accomplish their dreams and effect change (Henke et al., 1996:245). Nevertheless, the writers still find the image problematic (Henke et al., 1996:247).

\subsection{Gender Imbalance in Disney Animated Films}

Gender imbalance and inequality in Disney animated films are defined through two terms: 'male ensemble' and 'undercut' in the conclusions of Nina Huntemann and Michael Morgan's book Mass Media and Identity Development (2001). They found that it was common for men to outnumber women on primetime television without naming such a phenomenon by any term; they also described a similar occurrence where women on TV sometimes broke a stereotype in one aspect of their life but then fall back on another stereotype in a different part.

Based on the former conclusions, they analyze such significant concepts as the 'male ensemble' which describes the gender imbalance in the films where male characters outnumber the female ones, especially in the animated films. Another concept they highlight is the 'undercut' which refers to a female character showing promise breaking gender stereotypes in one scene only to be undercut in subsequent scenes in the film. By building female characters up or having them break stereotypes just to subsequently knock them back down and cast them in a traditional role is no better than never building them up in the first place. In conclusion, they found that Disney is progressing, which is encouraging, even though stereotypical elements have been still occurring.

For exploring female portrayals and analyzing gender roles in films worldwide, Dr. Stacy L. Smith, Marc Choueiti, and Dr. Katherine Pieper conducted a study entitled Gender Bias without Borders: An Investigation of Female Characters in Popular Films Across 11 Countries. They state that the picture of the man going off to work and the woman as a stay-athome mom is still present in contemporary films. They found that in the most ten popular American films released between 2010 and 2013, only 
$23.2 \%$ of the female characters had a job compared to $46.3 \%$ of the American women who actually had a job in the real world in 2012 (Smith et. al., 2014:6). Smith analyzed 120 films produced worldwide in total for her study and comes to the conclusion that more than threequarters of the characters who held a job were male and thus less than a quarter was female (Smith et. al., 2014:8). In conclusion, gender inequality is abundant and does not represent the reality in the international films.

Furthermore, in her study The Wonderful World of Gender Roles: A Look at Recent Disney Children's Films (2013), Elaina Donofrio studies four Disney animated films: Meet the Robinsons (2007), Bolt (2008), Princess and the Frog (2009), and Tangled (2010), in addition to four nonanimated Disney films produced in the same years: Bridge to Terabithia (2007), Bedtime Stories (2008), Race to Witch Mountain (2009), and The Sorcerer's Apprentice (2010), and the series of Harry Potter. In terms of gender, gender labels and bias are still present in the films. They reinforce gender stereotypes either by placing females at home doing domestic chores or through the dialogue.

However, some slight evolution has recently appeared in Libe G. Zarranz's study: Diswomen Strike Back? The Evolution of Disney's Femmes in the 1990s. She examined the "evolution undergone by some of Disney's female characters through the first years of the so-called 'Disney Decade' of the 1990s, paying special attention to the representation of sexual politics" (Zarranz, 2007:56). Zarranz coins the term 'Diswomen', which describes multi-faced, better-represented females compared to the subservient perfect girl. She cites Esmeralda in The Hunchback of Notre Dame as the best example of the Diswomen due to her resistance of stereotyped portrayal of femininity. In addition, she argues that she is the first successful Femme Fatale heroine in Disney as she is unpredictable, able to perform a sexual dance, stand as a devoted admirer of God, become defender of social injustice and act as a powerful Femme Fatale (Zarranz, 2007:60). Zarranz believes that more recent films have had more complex female characters. 


\subsection{Gender, Ethinc and Racial Stereotypes in Disney Animated Films}

Lianne Blankestijn, in her study From Snow White to Pitch Black: Gender and Racial Stereotyping of the Disney Princess (2015) studied six Disney princesses: Snow White, Aurora, Pocahontas, Mulan, Tiana, and Merida by means of a content analysis to recognize ethnic and racial stereotypes. The early princesses Snow White and Aurora possess only feminine traits, while the other princesses show a mix of masculine and feminine traits. The latest princess, Merida, even has far more masculine traits than feminine traits. Though Disney uses racial and ethnical stereotypes with moderation and care, she concludes that stereotypes were obvious seventy years ago in the portrayal of Disney's Snow White and that stereotypes are still visible in contemporary Disney princess films.

Since Snow White, the Disney princesses have become more masculine, the number of stereotypical feminine traits has been reduced, while the masculine traits of the princesses have been increased. Furthermore, Disney uses a moderate form of ethnical and racial stereotyping, with an exception of its latest princesses: Tiana, who may be a little too less of an African-American woman, and Merida, who may be too much of the stereotypical Irish. Blankestijn argues that the Walt Disney Company always wants to be on the safe side. After introducing new brave gender stereotypes, they seemed to have missed the point with the racial stereotypes in the latest films. Disney wanted a black princess for marketing reasons and to silence the critics of racism. Disney came up with a black princess with very little screen time and maybe too few black characteristics for black girls to identify with. It was safe enough to be a marketing success, but it was not enough to silence the criticism.

\subsection{Masculinity in Disney Animated films}

Britney Hibbeler, in her study Exploring Representations of Masculinity in Disney Animated Feature Films (2009) sheds light on the representations of male characters and representations of masculinity in Disney animated films. In her study, twenty-two movies, which were produced between 1930 and 2007 were examined. She analyzed the 
dimensions of character descriptions, physical descriptions, socioeconomic status, sexuality, family structures and practices, and aggression to highlight how constructions of masculinity in Disney films changed over time.

Based on her findings, Disney does not appear to be making progress towards more accurate and positive representations of male characters, which are portrayed as being younger, slender, sexual and romantically involved, aggressive, and as having family structures that are not commonly seen in society. These representations of male characters are very stereotypical in nature and may not provide young boys with positive role models for gender development.

Even though Disney films commonly portrayed the fatherhood movement in their films, slight progress has been made on themes regarding masculinity in more recent decades; these themes are beginning to embrace more current attitudes regarding masculinity. She concludes her research hoping that the Disney Corporation will continue to adopt updated attitudes regarding representations of masculinity in their films to provide more positive male role models.

\section{Feminist Film Theory}

Feminist film theory focuses on the function of female characters in film narratives or genres analyzing women portrayed in films. Additionally, feminist critique also deconstructs common stereotypes depicted in films, the extent to which the women were shown as active or passive, and the amount of screen time given to women. Analysis generally focuses on the meaning within a film's text and the way in which the text constructs a viewing subject. It also examines how the process of cinematic production affects how women are represented.

This paper is based on Laura Mulvey's study Film Theory and Criticism: Introductory Readings (Mulvey, 1975) as a reference to analyze patriarchal values presented through films. Mulvey uses psychoanalytic criticism to explore how film has been structured by the "unconscious patriarchal society" (Mulvey, 1975:803). Mulvey's argument provides a theoretical understanding of women's portrayal in films. The function of women in film, according to Mulvey, is to provide visual pleasure for men. 
Women are always at the end of a "male gaze" and are never the ones gazing (Mulvey, 1975:808). This is shown in both camera use, wherein the camera focuses on a woman's body, and through male characters gazing at women. What reinforces this is how women are portrayed. The appearance of women is "coded for strong visual and erotic impact" so they "connote to-be-looked-at-ness" (Mulvey, 1975:809). Mulvey, here, points out a tradition in cinema, one which reveals itself in Disney princesses. At a glance, all Disney princesses appear to be homogeneous in body type: each is slim, with a defined waist, full bust, long lashes, and large eyes. Laura Mulvey argues that in cinema, women are typically depicted in a passive role that provides visual pleasure. She views that, in film, a woman is the "bearer of meaning, not maker of meaning" (Mulvey, 1975:804).

\section{About the film}

In 2016, Moana was released by Walt Disney. After Maui, an ambitious, ego-centric and selfish demi-god, steals goddess Te Fiti's heart due to his thirst for power and heroism, all the pacific islands are affected, and nature starts dying. Maui violates the Mother Island, first by entering her cave and then by using his fishhook to rob her of her fertility. The disastrous repercussions of this act are the basis of the plot. Encouraged by grandmother, Moana, a 16-year-old Polynesian girl and the daughter of the chief of one of the endangered islands, starts her adventure on the sea, despite her father's warning not to approach the ocean. She risks her life to save her people and her island with Maui as her companion after she convinces him. At the end, Moana could successfully restore harmony after she undergoes many hardships in the ocean.

\section{Gender Role and Stereotypes in Moana}

\subsection{Being at One with Animals and Nature}

Unlike Snowwhite and Cinderella, though Moana is dark-skinned with curly black hair, who is dressed traditionally like all the girls of the tribe not like princesses, she is feminine in appearance, as well as nurturing, empathetic, emotional, and connected to nature. She wears a skirt and is always surrounded by flowers and trees, which all connote femininity. She is often surrounded by animals, which she looks out for: as a young child, 
she guides a turtle hatchling to the ocean; she is shown giving coconut water to Pua, the pig, removing Heihei, the rooster, from a fire, and removing a coconut husk covering Heihei's head. Like Rapunzel of Tangled, Moana is also shown calming Heihei and controlling him, stopping him from walking into the ocean and taking him as her only companion on her adventures in the ocean. Throughout the film, Moana stresses the fact that she is connected to the island and ocean as elements of nature.

\subsection{Masculine Traits: A Display of Power and Bravery}

In Moana, Maui is presented, as Grandma Tala explains, a demigod, warrior and shapeshifter, whose thirst for power makes him steal to possess the strongest power to become a real hero.

His physical portrayal is depicted as hyper-masculine as his body is strong, wide and big, clearly reflecting his temper and personality. Maui is characterized by a sense of superiority and total egocentrism despite being aggressive and violent. Due to his selfishness and irrationality, he locks Moana in the cave and runs away in her own boat. Hasn't it been first for her wittiness to get out of the cave without any support, then for the help of the ocean, Moana would have been left locked up inside the cave until she dies. He also misuses his masculine physical power to throw her many times from the boat to get rid of her company. Yet, he is not able to use such physical power to encounter and defeat either the Kakamora, violent coconut creatures, or Te Ka, the lava monster.

\section{Reversal of Roles and Deconstruction of Gender Stereotypes in Moana}

\subsection{Leadership: Women as Saviors}

Throughout her actions, Moana is authoritative and considered a leader. Unlike 'Disney Princesses', who are more domestic and likely to marry, the film ends by Moana being celebrated by her tribe signaling her future leadership as an heir to her father without referring to the issues of any love story, marriage or a prince as a savior. In his study Disney's Violent Women: In Quest of a 'fully real' Violent Woman in American Cinema (Toth, 2017), Toth points out that, despite the patriarchal norms to which most of Disney princess have to conform, Moana is giving advice to everyone, men and women, and nobody rejects her as a leader. Her 
song, which says "I can lead with pride", "I can make us strong" and the reply by the villagers "You will raise this island higher", connote successful leadership and authority that is not only welcomed by everyone, but also crucial for the improvement of her tribe. Moana is also shown interacting with her people, dancing with children, and giving advice and direction to villages (Toth, 2017:196). These actions do not only connote power and respect, but also wise authority over her people.

Furthermore, Moana exhibits self-confidence and believes in her own authority and leadership when she repeats "I am Moana of Montunui" and commands Maui to return the heart of Te Fiti that he has formerly stolen. Despite the assistance of the ocean, which is not male assistance, it connotes that Moana needed help to assure her authority over Maui. However, after his resistant rejection to her female authority, he surrenders to accept his role and emphasizes Moana's capability of leadership.

\subsection{Mobility and Physical Power}

Moana, unlike stereotyped Disney princesses, is surrounded by objects like oars and boats, which reflect traveling and mobility. She is also shown engaging in combat and a variety of physically demanding actions. First, at the beginning of her mysterious adventure, her boat flips and she gets stuck in the reef. After harsh struggle not to get drowned, she could survive. Despite her crying in defeat, she determines not to surrender to save her people. Then, she is shown fighting the Kakamora, violent coconut creatures, at the same time Maui, the demi-god surrenders and rejects the idea that he can defeat them without his magical fish-hook. In his study Images of Gender, Race, Age, and Sexual Orientation in Disney Feature-length Animated Films (Towbin, 2004), Towbin et al. highlight the reversal of gender roles as these actions connote not only mobility, but Moana's ability to take care of herself in dangerous situations without relying on him for protection, an aspect often absent in Disney's princesses, who usually wait for the charming prince to become their saviors (Towbin, 2004:30). Furthermore, reversal of gender roles is depicted when Moana saves Maui from Tamatoa, a giant-monster crab, to help him retrieve his hook, which signifies his male power as he former admits that he is nothing without his magical fishhook. 


\subsection{Old Women: Wisdom, Power and Guidance}

Unlike the presentation of old women in most of the classic fairytales or Disney films like the step-mothers in Cinderella and Snowwhite or Gothel in Rupanzel, Tala, Moana's grandmother, has a different portrayal. She is presented as a very old woman with the silver, curly hair; she is not depicted as the selfish villain, who seeks power and beauty, or the weakhelpless woman who needs support from others. She says about her son, the chief of the tribe that she is his mom who doesn't have to tell him anything, which reflects her power as a mother, even over the leader of the island.

Furthermore, though she exhibits supernatural powers, her power is reflected through her strong character, not like the Godmother in Cinderella who only uses restricted magic to help Cinderella temporarily, to guide and encourage Moana going overseas to save her people. That is, Tala relies on her experience and knowledge, rather than magic, which is shown when she guides Moana to the ancient boats as a means of mobility.

The reversal of gender roles is reflected in Tala's support, as an example of female power of knowledge and experience, usually portrayed through male characters in other Disney films and fairy tales. She tells Moana: "Go, (...) The things you have learned will guide you (...) Nothing on earth can silence the quiet voice inside you". These powerful words celebrate the value of knowledge and determination rather than conform to the social conventions and norms. Finally, Tala defies the traditional Disney portrayal of elderly characters being depicted as forgetful, weak, helpless, and submissive or villains, which is seen more often than they are shown as wise (Towbin, 2004:35).

\subsection{The Ending: Not as Usual, Happily Married Ever After}

Before 2000, Disney princesses' films were more likely to end 'and they lived happily ever after' after winning the heart of a man, to be her savior and the only solution for all the hardships that the princesses have to undergo. In the course of time, concepts and values have changed, and Disney has had to start marketing for new ideas and presenting more diverse and balanced characters that can be more appropriate for its viewers. It does not display romantic love and ideal optimism in marriage 
as the final destination and the sought dream for its female protagonists; nevertheless, it has started depicting their struggle it has started depicting their struggle for broader the greater good, enabling and empowering them.

In Moana, Moana starts as an independent girl, who is self-confident that she can save her people and island from imminent destruction. After long adventures and hardships accompanied by Maui, the demi-god, she could not only survive but also rescue her people foreshadowing her leadership in the future as an heir to her father.

The film ends with as a savior and Maui's overwhelmed happiness by his new fishhook that would help him regain his magical power. There is break from the convention of 'they lived happily ever after'; there is not even any connotation of any future romantic relationship between both of them, but rather mutual respect and appreciation.

\section{Conclusion}

This paper is meant to illustrate the progress made concerning the representation of female characters in relation to the male one in Disney films. Moana (2016) is deconstructed by analyzing and employing elements such as: dialogue, arguments, songs, images, and actions. Feminist film theorist Mulvey provides a theoretical framework. Moreover, this study is set within the context of cultural studies and film theory.

The study concludes that despite the still existing gender stereotypical traits in Moana (2016), the film proves to be a successful attempt to progress beyond traditional patriarchal values and provide a good example of gender portrayal. Though Moana is not a princess, but the daughter of a chief of an island, she is portrayed as a positive female model who can be a source of salvation instead of submissiveness and servitude. She is able to celebrate femininity and exercise power and authority over her people through her uncontested leadership. In her study Disney's Modern Heroine Pocahontas: Revealing Age-old Gender Stereotypes and Role Discontinuity under a façade of Liberation (Dundes, 2001), Dundes argues that "portrayals that reinforce limitations on women's function in society should be replaced with roles that place no boundaries on what women can achieve" (Dundes, 2001:363), and Moana is one arguably of the first Disney heroines to display that. 


\section{References}

1. Blankestijn, L. M. (2015). "From Snow White to Pitch Black: Gender and Racial Stereotyping of the Disney Princess." S4261968.

2. Cott, Nancy F. (2009). Public Vows: A History of Marriage and the Nation. Harvard University Press. Google Book Search. Web. 13 Jun. 2015.

3. Devor, H. (1992). Becoming Members of Society: Learning the social meanings of gender. In M. Schaum \& C. Flanagan (Eds.), Gender images: Readings for composition. Boston, MA: Houghton Mifflin Company.

4. Donofrio, E. M. A. (2013). The Wonderful World of Gender Roles: A Look at Recent Disney Children's Films. Boston College.

5. Dundes, Lauren (2001). Disney's Modern Heroine Pocahontas: Revealing Age-old Gender Stereotypes and Role Discontinuity under a façade of Liberation. The Social Science Journal, 38, MD 21157-4390, USA.

6. Durkin, K. (1984). Children's Accounts of Sex-role Stereotypes in Television. Communication research: 341-362. Web. 24 May 2015.

7. Henke, J. B., Umble, D. Z., \& Smith, N. J. (1996). Construction of the Female Self: Feminist Readings of the Disney Heroine. Women's studies in communication.

8. Hibbeler, B. Lynn. (2009). "Exploring Representations of Masculinity in Disney Animated Feature Films." Unpublished Thesis. Retrieved on April 21, 2014 from repository. tamu. edu/bitstream/handle/1969.../HIBBELERTHESIS. pdf.

9. Huntemann, N., \& Morgan, M. (2001). Mass Media and Identity Development. In D. Singer \& J. Singer (Eds.), Handbook of children and the media. London, England: Sage Publications, Inc.

10. Moana. (2016). Ron Clements \& John Musker (dir.), Jared Bush (scr.), Osnat Shurer (prod.).Walt Disney Pictures. United States.

11. Renold, E. (2005). Girls, Boys and Junior Sexualities: Exploring Children's Gender and Sexual Relations in the Primary School. New York, NY: Routeledge Falmer. 
12. Mulvey, L. (1975). Visual pleasure and narrative cinema. In I. Braudy \& M. Cohen (Eds.), Film theory and criticism: Introductory readings (pp. 803-816). New York, NY: Oxford University Press.

13. Ross, D. (2004). Escape from Wonderland: Disney and the Female Imagination. Marvels \& Tales: Journal of fairy---tale studies, 18(1), 53---66.

14. Smith, Stacy L. Marc Choueiti, and Katherine Pieper (2014). Gender Bias without Borders: An Investigation of Female Characters in Popular Films Across 11 Countries. Seejane.org. Geena Davis Institute on Gender and Media. Web. 26 May 2015.

15. Tobin, J. (2000). Good Guys Don't Wear Hat: Children's Talk about the Media. New York, NY: Teachers College Press.

16. Toth, Z. A. (2017). Disney's Violent Women: In Quest of a 'fully real' Violent Woman in American Cinema. Brno Studies in English.

17. Towbin, M. A., Haddock, S. A., Zimmerman, T. S., Lund, L. K., \& Tanner, L. R. (2004). Images of Gender, Race, Age, and Sexual Orientation in Disney Feature-length Animated Films. Journal of Feminist Family Therapy.

18. Zarranz, L. G. (2007). Diswomen Strike Back? The Evolution of Disney's Femmes in the 1990s. Atenea. 